\title{
Back to basics for high-energy physics
}

US panel's

ritual defence

of accelerator

\section{Washington}

The high-energy physics community in the United States is lifting only the littlest of fingers in defence of the proton-antiproton accelerator ISABELLE at the Brookhaven National Laboratory, Long Island. At a day-long meeting on Sunday, the influential High Energy Physics Advisory Committee accepted a subcommitee's recommendation that the accelerator should be completed only if there were a prior assurance of adequate support for research at the two other accelerator laboratories at Stanford, California, and Fermi National Accelerator Laboratory (Fermilab), Illinois.

ISABELLE may thus turn out to be the most conspicuous casualty of the new financial restraint. The physical infrastructure of the machine, a tunnel 2.5 miles in circumference, is 95 per cent complete. But something like a further $\$ 500$ million would have to be spent on magnets, vacuum systems and radio-frequency accelerating cavities if the accelerator was to be finished by 1990 .

If the project is abandoned, some 400 technical people at the Brookhaven Laboratory will be without jobs. There is even the gloomy possibility that, without its chief task, the survival of the laboratory itself will be in jeopardy.

The subcommittee report, the sole item on Sunday's agenda, had been prepared in less than three months by a group under $\mathrm{Dr}$ George Trilling of the University of California, Berkeley. The panel will go on to produce a more measured statement in January of the benefits that may derive from particle accelerators based on novel principles such as those being developed at Stanford and Cornell universities. This week's interim report was made necessary by the Department of Energy's need of an opinion from the high-energy physics community in advance of this week's crucial decisions within the Administration on how the latest 12 per cent budget cuts will be distributed.

Given the conflicting interests of its members, the panel's chief conclusion is understandably delphic. It "strongly recommends" that ISABELLE should be completed, goes on to argue that the tota! cost of high-energy physics to the Department of Energy would then be $\$ 440$ million a year and remarks that if this support is not forthcoming, the ISABELLE project cannot be continued.

At present, high-energy physics is

operating on a budget of $\$ 325$ million a year, at which level the principal accelerators cannot be operated full time for lack of funds with which to pay the electricity bills.

There is every sign that high-energy physics has reached a turning point in the United States. Three distinguishable constituencies have emerged - the operators of the accelerators at Fermilab and Stanford, who wish to see their equipment fully used, the adherents of ISABELLE, who argue that it is an essential tool for the $1990 \mathrm{~s}$, and the general university users of accelerators, who need more immediate access to existing machines but who recognize that without ISABELLE they will have even fewer experimental opportunities ten years from now. The interim report spells out the conditions that must be satisfied before funds are spent on the completion of ISABELLE:

- Full utilization of existing accelerators. - Completion of the Tevatron I accelerator upgrade for colliding 1,000 $\mathrm{GeV}$ protons and antiprotons based on existing Fermilab accelerators.

- A start on work on the Tevatron II

\section{Top men resign in CNRS crisis}

The two heads of the largest research agency in France - the Centre National de la Recherche Scientifique (CNRS) - fell last week in a self-delivered coup de grace.

On Wednesday, M. Jacques Ducuing, the director-general of CNRS, handed in his resignation to the minister for research and technology, M. Jean-Pierre Chevènement. Shortly after, the president of CNRS, Professor Charles Thibault who worked in tandem with Ducuing resigned also. He was followed by three of the six scientific members of the CNRS council, and the other three, including Louis Néel, a Nobel laureate representing the Académie de France, are likely to resign soon. (Néel, however, awaits the recommendation of the Académie.)

So what was the fuss? Chevènement was planning to wait until early next year before making any major changes at CNRS (and elsewhere) by which time he would have tested the water with the national colloquium on science and technology. The unions were unhappy with the CNRS directorate and had called for their resignation; but there was no sign of any movement yet.

Then, on Tuesday, after a long Socialist Party congress in which the party appeared to move to the left and chided the government for failing to confront the establishment more firmly, Chevenement decided he wanted to sack M. Christian Morrisson who was appointed director of social sciences at CNRS in April (before the general election).

Morrisson, it seems, was taking CNRS project, intended as the chief fixed-target accelerator for the 1980s.

- Development of superconducting radio-frequency cavities (at Cornell University).

- Development of novel accelerator designs.

Much of Sunday's meeting was occupied with the cost of this minimal programme, eventually fixed at $\$ 395$ million a year: if ISABELLE were to be completed, the total high-energy physics budget of $\$ 440$ million a year would include an average of $\$ 80$ million a year for the construction of the machine. If, however, ISABELLE is abandoned, the committee argued, it would be necessary to spend an extra $\$ 35$ million on research and development on new accelerator technology.

The committee's optimism that its "minimal" programme may be funded derives from the agreement in 1979 between the Department of Energy and the Office of Management and Budget that high-energy physics could count on a budget of $\$ 300$ million a year, adjusted for inflation. Several members argued that even with the completion of ISABELLE,

social science in completely the opposite direction from Chevènement's own interests. The minister would like to expand social sciences in France, but in the direction of immediate public concern such as unemployment, or the changes implied by new technologies. Morrisson's interests were more academic.

So Chevènement called Ducuing and asked him if at the council meeting due the following day he would propose that Morrisson be replaced by someone more sympathetic - a M. Maurice Godelier, professor of anthropology at the Ecole des Hautes Etudes. Ducuing asked for more time to consult his colleagues but was refused. $\mathrm{He}$ resigned, and the other resignations followed, on the principle that the minister's insistence was an interference with scientists' responsibilities.

Chevènement, however, did not seem too disturbed by the events, despite the cries of some that the resignations would throw out of joint his whole plan for the reorganization of science and technology in France. At a press conference on Wednesday he asked journalists why they were so excited about the affair, pointing out that he had only proposed one change whereas in America the whole top administration was turned over at a change of government.

The minister now has a clear field on which to place his men, well before he had expected the opportunity. $\mathrm{He}$ is likely to be quick to make new appointments, though they must be approved by the council of ministers.

Robert Walgate 
their budget is in real terms not very different from what was agreed three years ago. Others say that little purpose is served in reminding one Administration of promises made by its predecessor.

One of the ironies of ISABELLE is that the problems of magnet design which have delayed the project by about four years appear in the past few weeks to have been resolved. If the Administration practises what it has been preaching the only remaining hope for the accelerators is that Congress may choose to appropriate funds for the project against the Administration's wishes.

\section{High-energy physics}

\section{LEP approved}

While American physicists agonize over the future of a new accelerator (see above), twelve European nations last week agreed in principle to the construction of LEP, a $27-\mathrm{km}$ circumference machine to collide electrons with positrons at energies up to 50 $\mathrm{GeV}$ per beam - enough to create the longsought neutral intermediate vector boson.

The twelve nations are the members of CERN, the European centre for research on nuclear physics at Geneva where LEP will be constructed. Three members (the Netherlands, Sweden and Norway) have given approval subject to parliamentary approval at home.

The principal questions still hanging over LEP concern the precise annual budget at which it will be built - which affects how rapidly it might be brought into service - and environmental opposition in the French and Swiss territory under which the LEP tunnel must be bored.

If all goes well the budget will be decided at the December meeting of CERN Council. (On CERN's own plans, it would be about 630 million Swiss francs a year $£ 182$ million - enough to have LEP in action by early 1987. )

But environmental approval is more unpredictable. At present, CERN is restricted from building even a reconnaissance gallery. The gallery is needed to permit inspection of the geologically critical boundary between the sandstone floor of the Geneva valley and the limestone Jura Mountains to the north (under which the LEP tunnel must pass), but a Lyons court ruled that CERN had no valid licence for the work. CERN has now guaranteed that the accelerator will not be built until and unless the appropriate local French and Swiss procedures for approving large constructions are completed successfully.

Such approval is yet to come - for the French and Swiss accession to LEP at the level of CERN Council was made at ministry level, and is subject to local approval. However, CERN staff are confident that the environmental "dangers" of LEP - for example that it might affect the water table - have been wildly exaggerated, and that local approval will be granted.

\section{US research support}

\section{Academy exhales}

\section{Washington}

Dr Frank Press's first essay as a constituency lobbyist since his election as president of the National Academy of Sciences, his colloquium on the latest budget proposals on Monday and Tuesday last week, was a tactical success. Its most tangible product, a document labelled "consensus statement", drafted in a closed session on the second day, is a nice amalgam of moderate belligerence and sympathy for the Administration's economic problems.

The colloquium itself was the first response of what the labour unions might call organized science to the decision in September that all federal agencies except the Department of Defense must reduce their discretionary expenditure by 12 per cent. (NASA, for the current financial year, is let off lightly at 6 per cent but has been told that 1983 will be worse). Discretionary expenditure is that not mandated by explicit provisions in legislation.

The consensus statement acknowledges that economic problems "have eroded research and development", but says that the new budget proposals will do "irreparable damage" unless long-term research is protected, if necessary at the expense of "development and demonstration'". The document urges the Administration to assume responsibility for supporting scientific research, but asks for a formal review of the machinery by which this is done.

Before the definition of consensus preoccupied the colloquium, diversity was rampant. One speaker was so alarmed by the threatened 12 per cent reduction as to fear a return to pre-Sputnik days. Another warned his academic colleagues not to expect too much from industry, whose support now accounts for 3 per cent of university budgets. Industrial grants would have to increase threefold to make good the damage done by the 12 per cent cut.

The colloquium also broke new ground by giving currency to the word "prioritization" - deciding what research should be given first claim on limited funds. This notion is in sharp contrast with earlier declarations of faith in a plurality of sources of funds.

The statement argues that the abruptness of the new cuts will be especially damaging. This is well illustrated by the plight of the National Science Foundation, none of whose expenditure is mandated by Congress, but which finds itself committed to the US Navy for support of the Antarctic research programme as well as to several national laboratories. It has become known in the past few days that these commitments may mean that the softer, grantmaking parts of the foundation may find their budgets cut by up to 18 per cent, especially if spending on social science, education and international relations (cut severely in March) is now protected.

Among the hundred participants the two principal government representatives appear to have left contrasting impressions on their audience. Dr J. Khaduri, one of the hard men from the Office of Management and Budget, preached economic realism and told his listeners that they would lose more from continued inflation
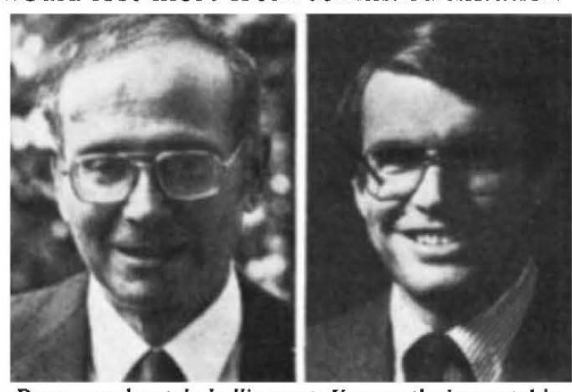

Press, moderately belligerent; Keyworth, inscrutable than from the government's emergency budget. In the meantime, he declared, there is bound to be hardship. But at least there is also a chance that scientific enterprise could be growing again on the basis of a "new equilibrium" and with the help of dollars whose value remained constant from one year to the next. It is unfortunate that the Secretary of the Treasury, Mr Donald Regan, should have had to admit a few days later that the federal budget would probably not be balanced by 1984 .

Dr George Keyworth's declaration seems to have been harder to interpret. The science community is not yet sure whether to regard him as a friend at court or as the Administration's lightning rod. Dr Keyworth himself is probably not yet sure. Last week, however, he left at least some of his audience with the impression that he believes the consequences of the emergency budget will be less serious than now seems likely. Does he know something, or is he simply being well mannered?

\section{European space policy \\ New satellites due}

Europe's activities in space received new impetus with the announcement last week that the United Kingdom is willing to make its contribution to the Large Telecommunications Satellite (LSAT-1), and with the decisions made at a European Space Agency (ESA) council meeting to recommend three projects to member nations for further development. Provided the member states do not refuse to fund them, the three projects - the Earth Resources Satellite (ERS-1), the Ariane 4 launcher and the Spacelab "follow-on" spacecraft - will begin their next development stages in about three months' time. Other issues of great concern to the members of ESA - particularly collaboration with the United States and the ten-year plan of ESA's director, Erik Quistgaard (Nature 290, p.536) - have 